\title{
“Etude Vocalizing” Interactive Video Design for Junior High School Student
}

\author{
Novia Dwi Lestari*, Yudi Sukmayadi \\ Universitas Pendidikan Indonesia \\ Bandung, Indonesia \\ *noviadwilestari.nd@gmail.com
}

\begin{abstract}
This article discusses about the process of designing video-based etude vocalizing technique for junior high school students as an interactive supporting learning media. The research is aimed to provide a recommendation for alternative learning media concerning etude in vocalizing through interactive video, because in online learning era, it is considered quite helpful for junior high school students in general because the flexibility and interactive ability of this video media to combine texts, images, music, voices, and animation. The steps for this research included (1) Gathering materials; (2) Creating etude; (3) Planning Concepts and Product Designs; and (4) Product Making. The result of this article is an interactive video of compilation of etude vocalizing, which is expected to be a recommendation alternative media in learning. So it is hoped that this interactive video learning media can help teachers in presenting an interesting new alternative and can also help students understand and accept the music learning process. This media is intended for junior high school students in general who want to practice vocals but are less able to master vocalizing techniques as textually (etude) or practice (technique).
\end{abstract}

Keywords-learning media, interactive video, etude vocalizing

\section{INTRODUCTION}

During the ongoing modernization era where technology rapidly developing, many learning media emerges with various interesting features and design. One of which is interactive video. This media is considered helpful as it could give supports the course of learning, as learning processes would always require interaction so that learning materials would be easier to be understood as well as keep the learners entertained. Those interactions could be obtained when students are actively involved during the learning process by the acts of responding the learning materials presented. Generally, benefits that could be gained from interactive video-based learning is the evidently more interesting and interactive learning that is also efficient, as the teaching (lecturing) time could be reduced, the more flexible learning time and place as it could be done at any place and time, and the more focused students' attention. Furthermore, the interactive video could be downloaded to various devices such as personal computer, laptop, handphone, tablet, and many other gadgets so that it could be accessed by every user. The benefits of using multimedia was also explained by Lee [1] who stated that at least there are eight reasons to use gadgets as learning media; those are experiences, motivations, enhanced learning processes, authentic materials, interactions that are broader, more personal, and not fixated on a single source and global understanding. Phillips [2] also stated that "IMM has the potential to accommodate people with different learning style". It could be understood as interactive media has the potential to create a multisensory environment that could favor certain learning style. The development of technologies encourages the researchers to utilize interactive video as a learning media for etude vocalizing. As for the researchers' interest that became the focus of the research is the product designing for etude vocalizing learning media in the form of interactive video. The planning of the core form of the video was a basic explanation about vocalizing and etude vocalizing starting from the types of vocalizing that are easy for junior high school students to imitate up until the ones that tend to be difficult for them through appealing interactive video.

\section{LITERATURE REVIEW}

Etude could be interpreted in verbatim as practice or lesson. According to Banoe [3] etude is "music composition that is prepared with the purpose of training one's music playing skills". Generally, etude melodies are very simple, even though there are some which has high level of difficulty. That is where a musician is required to be able to interpret a simple etude to become very rich and impress their audience. On the other hand, according to Lucky [4] vocalizing is an activity to flexes the vocal cords and to avoid stiff vocal cords that could cause one's voice became less pleasant to be listened to. Vocalizing must be done with supporting techniques that include the correct posture, breathing technique, and the utilization of sound positioning.

Last but not least, multimedia, as defined by Lestari [5] is the combination of various media such as texts, sound, images, and video. Those combinations are integrated into computers to be stored before processed and presented at the same time. This multimedia is made with the purpose to maximize every sense in receiving certain information so that it could be used to deliver messages to public. On the other hand, according to 
Lestari [5] the term of interactive is related with two-ways (or more) communication from the communication components themselves. As for the components of communications within an interactive multimedia, they are: relationship between human (as user) and computer (as media). In interactive multimedia, interaction is one of the most prominent features to support active learning process. Not only it allows the users to see and hear but also it could actually do something.

\section{METHODS}

Methods used in this research is qualitative and the data collection technique used was observations, interviews, and documentations. The research design conducted included (1) material gathering, where the researchers conducted observation towards etude vocalizing starting from the ones that are easier to be imitated by junior high school students until the ones that are the most difficult. The observation was conducted by reference streaming through YouTube and interviews. Due to the researchers' limited movement during the research caused by lockdown and social distancing policies, the majority of data gathering techniques conducted by the researchers was via gadget. (2) Interviews, where the interviewees included work as vocal lecturers, choir coaches, vocal trainers at non-formal schools and conducted through WhatsApp messages through text messages, video calls, voice notes, and recordings that later attached into Documentation. Besides, the researchers also conducted this research using non-human sources such as videos and referential recordings from YouTube. Moreover, the researchers substantiate the findings with reading materials, internet-based materials, and previous studies as references. Hopefully, the data gathered results to expected research result.

\section{DISCUSSION}

\section{A. Interactive Video as Learning Media}

Interactive video or interactive multimedia according to Robin and Linda [6] is a tool to create dynamic and interactive presentation as well as combining texts, graphics, audio, and video. Learning technology in the form of multimedia is one of learning media that could be utilized by teachers as the general benefits that could be gained includes its higher appeal, higher interactivity, lesser teaching/lecturing time, higher students' learning quality as they could be more motivated, very flexible teaching and learning process (can be done at any time and place), as well as more enhanced and focused students' attitude and attention. Bearing those in mind, hopefully learning process could be transpired, have purposes, and controlled.

\section{B. Gathering Etude Materials}

Etude materials gathering techniques that were used by the researchers was preliminary study interview towards competent interviewees, especially those who are competent in the field of vocal training for junior high school students. The researchers interviewed 4 interviewees, those are Kang Reza who works as a musical teacher as well as choir coach in various schools,
Kang Adjie who works as vocal trainer at dotodo music School, Shiena Bias Fajhrin as musical teacher as well as choir coach at SMP Al-Aqsa, and Tizza Lucky who works as musical teacher and choir coach in a junior high school in Jakarta. The interviews were conducted through WhatsApp text messaging as well as voice notes due to lockdown and social distancing policy and included 3 questions, consisted of: (1) what kind of vocalizing techniques that are being taught to junior high school students? (2) what kind of vocalizing techniques that are tend to be easier to be understood and imitated by junior high school students? (3) what kind of vocalizing techniques that are tend to be harder to be understood and imitated by junior high school students? From the three questions asked towards the various interviewees, the following simplified answers were gathered

1) What kind of vocalizing techniques that are being taught to junior high school students?

Reza : Humming, Thrilling, Articulation, Musical Scale, Arpeggio.

Tizza: Humming, Articulation, Interval, Song (Naik Delman) to boost students passion.

Adjie : Humming, Lips Thrill, Tongue Thrill, Interval, Articulation, Chromatic Arpeggio

Shiena Bias: Humming, Articulation, Musical Scale with $1 \frac{1}{2}$ Octave, Arpeggio.

2) What kind of vocalizing techniques that are tend to be easier to be understood and imitated by junior high school students?

Reza: Humming, Thrilling. It is caused by the easy techniques and the notes have the impression of "stepping" instead of "jumping" so they are easier to be imitated.

Tizza: Humming, Articulation. Because the pitch distances are approachable by the students.

Adjie: Humming, Lips Thrill, Tounge Thrill. Because the technique and the pitch interval are simple.

Shiena Bias: Humming and Articulation. Because the pitch intervals were not too far from each other so it is easier for the students to imitate.

3) What kind of vocalizing techniques that are tend to be harder to be understood and imitated by junior high school students?

Reza: Musical Scale, Arpeggio. Because the pitch interval has the impression of jumping so the students sometimes are confused and pitchy.

Tizza: Articulation, Interval. Sometimes the students find it difficult to articulate when the note range is difficult to be reached like in the ones with far-distanced pitch intervals.

Adjie: Interval. Chromatic Arpeggio. Because the students are not used to notes that are jumpy and chromatic. 
Shiena Bias: 11/2 Octaves, Arpeggio. Due to the distant pitch range.

From the answers gathered, it can be concluded that the vocalizing techniques taught to junior high school students are Humming and Thrilling which are considered easy. Articulation is considered to have medium difficulty (not too easy nor too difficult) and Musical Scale/Interval and Arpeggio considered to be the difficult ones. Apart from interviews, the researchers also conducted non-human research by accessing books, videos, documents, and file records regarding the topics of etude and vocalizing for junior high school students.

\section{Creating Etude as Interactive Video Material}

After obtaining data from the preliminary study, the researchers created etude material based on the interview conducted and reference from etude Yamaha Music Book as well as other reference video by transcribing the existing data using Sibelius, a software specified to type musical notations in the form of musical notes. In this stage, the researchers categorized the data obtained into three types, those are easy, moderate, and difficult.

\section{1) Easy}

a) Humming: Humming is one of the techniques to do vocal warm-up before singing. Humming could be done in various ways. Each method has its own role in vocal warm-up. Humming material given to every member to start sing notes starting from humming some range of notes with initial tonality of $\mathrm{C}$ then raised half a note until they reached $\mathrm{F}$. It could also be done from initial tonality of $\mathrm{G}$ then raised half a note until they reached g2 (see figure 1 and 2).

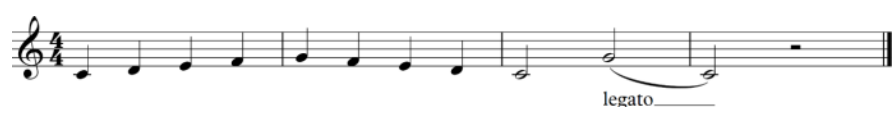

Fig. 1. Humming notation 1. Transcribed by: Novia Dwi L.

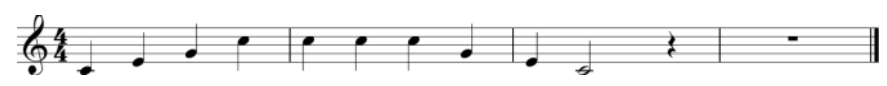

Fig. 2. Humming notation 2. Transcribed by: Novia Dwi L.

b) Thrilling: Thrilling technique consisted of lips thrill and tongue thrill that could be done by thrilling one's lips and tongue while humming some range of tones with the initial tonality of $\mathrm{C}$ then raised half a note until they reached $\mathrm{F}$. It could also be done from initial tonality of $G$ then raised half a note until they reached $\mathrm{g} 2$ (see figure 3 and 4 ).



Fig. 3. Lips thrill notation. Transcribed by: Novia Dwi L.

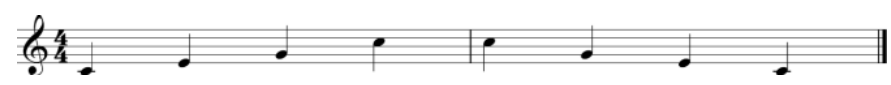

Fig. 4. Tongue thrill notation. Transcribed by: Novia Dwi L.

\section{2) Moderate}

a) Articulation: Articulation is a way to pronounce words while producing sounds. Improving clear articulation means improving the way someone pronouncing words so it will be easier to understand. The similar definition was also stated by Rudy (as stated in Maudina) [7] The term of articulation referred in the terms of music studies is the clear and correct pronunciation of words within song lyrics. The main requirements for a singer when singing a song is that they must master and memorize song lyrics by heart. Moreover, when singing a song, the emphasize takes precedence in clear and firm pronunciation of words so that the song become more distinguishable, lively, and heartwarming. Articulation in vocalizing conducted by singing ranges of note while the mouth must be open wide according to the letters that are being pronounced as well as moving tongue and lips, initiated with initial tonality of $\mathrm{C}$ then raised half a tone until they reached $F$. It could also be conducted by using initial tonality of $G$ then raised half a tone until they reached g2 according to notations that could be read as follows figure 5 and 6.

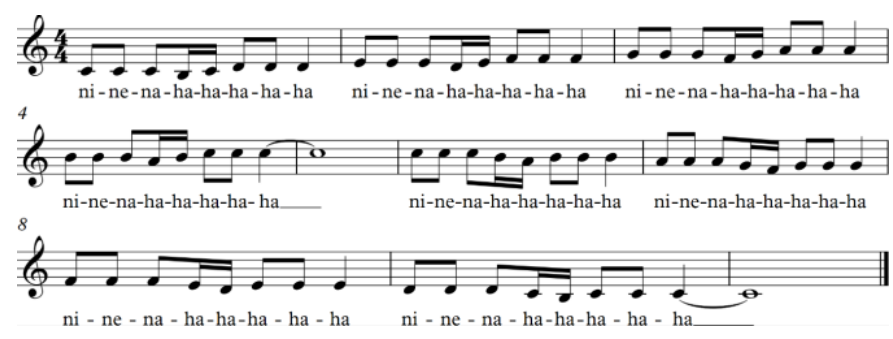

Fig. 5. Articulation notation 1. Transcribed by: Novia Dwi L.

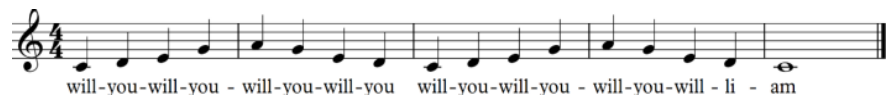

Fig. 6. Articulation notation 2. Transcribed by: Novia Dwi L.

\section{3) Difficult}

a) Interval: Interval conducted by singing musical scales using solmization techniques depending on the notation being read. It is initiated by singing initial tonality of $\mathrm{C}$ then raised half a note until they reached $F$. It could also be conducted by using initial tonality of $\mathrm{G}$ then raised half a tone until they reached $\mathrm{g} 2$ according to notations that could be read as follows figure 8 . 


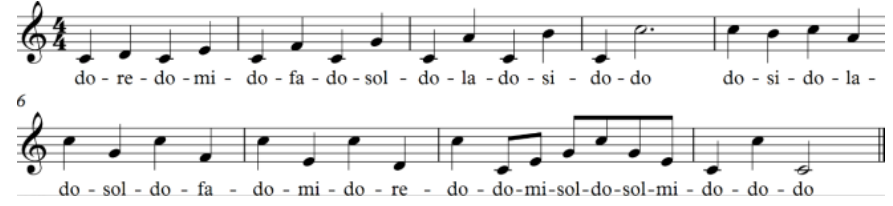

Fig. 7. Interval notation 1. Transcribed by: Novia Dwi L.

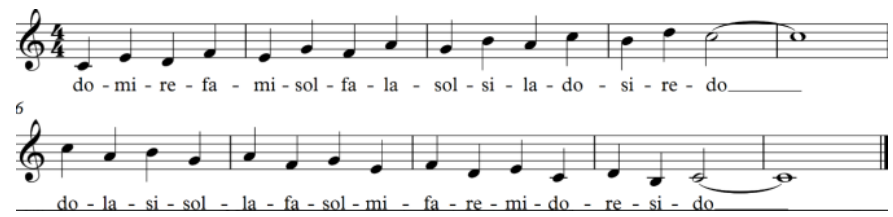

Fig. 8. Interval notation 2. Transcribed by: Novia Dwi L.

b) Arpeggio: Arpeggio is a musical scale practice using a more difficult range as the melodies are jumpier; or as stated by the interviewees, arpeggio is considered difficult since the distance between each pitch is quite far so it would be difficult for junior high school students. Arpeggio is done by singing solmization that is initiated by singing with the initial tonality of $\mathrm{C}$ then raised half a tone until they reach $\mathrm{F}$. It could also be conducted by using initial tonality of $\mathrm{G}$ then raised half a tone until they reached $\mathrm{g} 2$ according to notations that could be read as follows figure 9 and 10 .

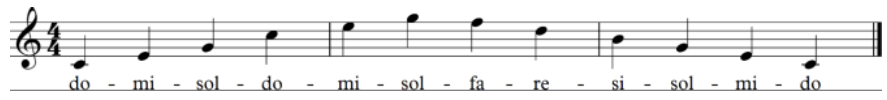

Fig. 9. Arpeggio notation. Transcribed by: Novia Dwi L.

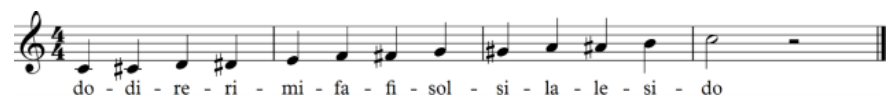

Fig. 10. Chromatic Arpeggio notation. Transcribed by: Novia Dwi L.

c) Planning concepts and interactive video designs: After the researchers planned etude vocalizing technique, the next step is to plan concepts and design video. The concepts of the video were designed according to interactive theme. Accordingly, the video not only require attractive design and completeness of the material but also good communication points, both verbal and gesture to engage with the audience. The video was designed by the research to be simple yet still complete and interesting. Within the video frame, there is one narrator who explained the vocalizing and etude theories, where after they are explained descriptively, it is followed by vocalizing practices starting from the easiest techniques to the most difficult ones according to the data obtained and processed previously. Besides, there are also narrators who practices the techniques. The etude vocalizing techniques is also attached in the video so that the audiences could get complete vocal training that consists of description, demonstration, and etude. The video was made using a software for video editing, namely Filmora. This software is available in both Windows and Mac systems and equipped with nifty in-built editing tools. The main highlight of this software is its simplicity, clear and intuitive interface, compatibility with almost all computer operating system and high processing speed. There are also advanced features and text editing tools such as color editing, font, and text and title animation. Hence, the software could facilitate the researchers to plan etude vocalizing interactive video media for junior high school students.

\section{CONCLUSION}

Based on the explanation above, it can be concluded that the interactive video design "Etude Vocalizing" for junior high school students, the researchers made with the stages described, is expected to help recommend an etude learning design in vocalizing to present a new learning alternative so hopefully it can helps students to understand and accept the process of music learning, especially for students who want to practice vocals but are less able to master the techniques as textually (etude) or practice (technique) because of the dynamic and interactive nature of this learning media which also combines text, graphics, animation, audio, and video. It is hoped that this design and research can be useful for researchers in particular and readers in general.

\section{REFERENCES}

[1] W.W. Lee and Owens, Multimedia based instructional design (2th ed.) (San Francisco: Pfeiffer), 2004.

[2] R. Phillips, The developer's handbook to interactive multimedia: A practical guide for educational applications. (London: Kogan Page), 1997.

[3] P. Banoe, Kamus Musik. (Yogyakarta) available at: https://repository.uksw.edu/. 2003.

[4] T. Lucky, Pembentukan Teknik Vokal Head Voice Pada Paduan Suara Mahasiswa Universitas Pendidikan Indonesia. (Bandung). Available at: http://repository.upi.edu/. 2018.

[5] N. Lestari, Media pembelajaran berbasis multimedia interaktif. (Klaten: Lakeisha), 2020.

[6] L. Robin, Menguasai Pembuatan animasi dengan Macromedia Flash (Elek Media Komputindo). Available at: https://studentactivity.binus.ac.id/himsisfo/2016/10/pengertian-multimediainteraktif. 2001.

[7] L.A. Maudina, Proses Pembelajaran Artikulasi Lagu Dalam Pembelajaran Vokal Untuk Anak Usia 7 Tahun (Studi Kasus Di Al Mozart Music Course \& Studio Kudus). Available at: https://lib.unnes.ac.id/. 2015 